\title{
Inhaltsverzeichnis zu Band I.
}

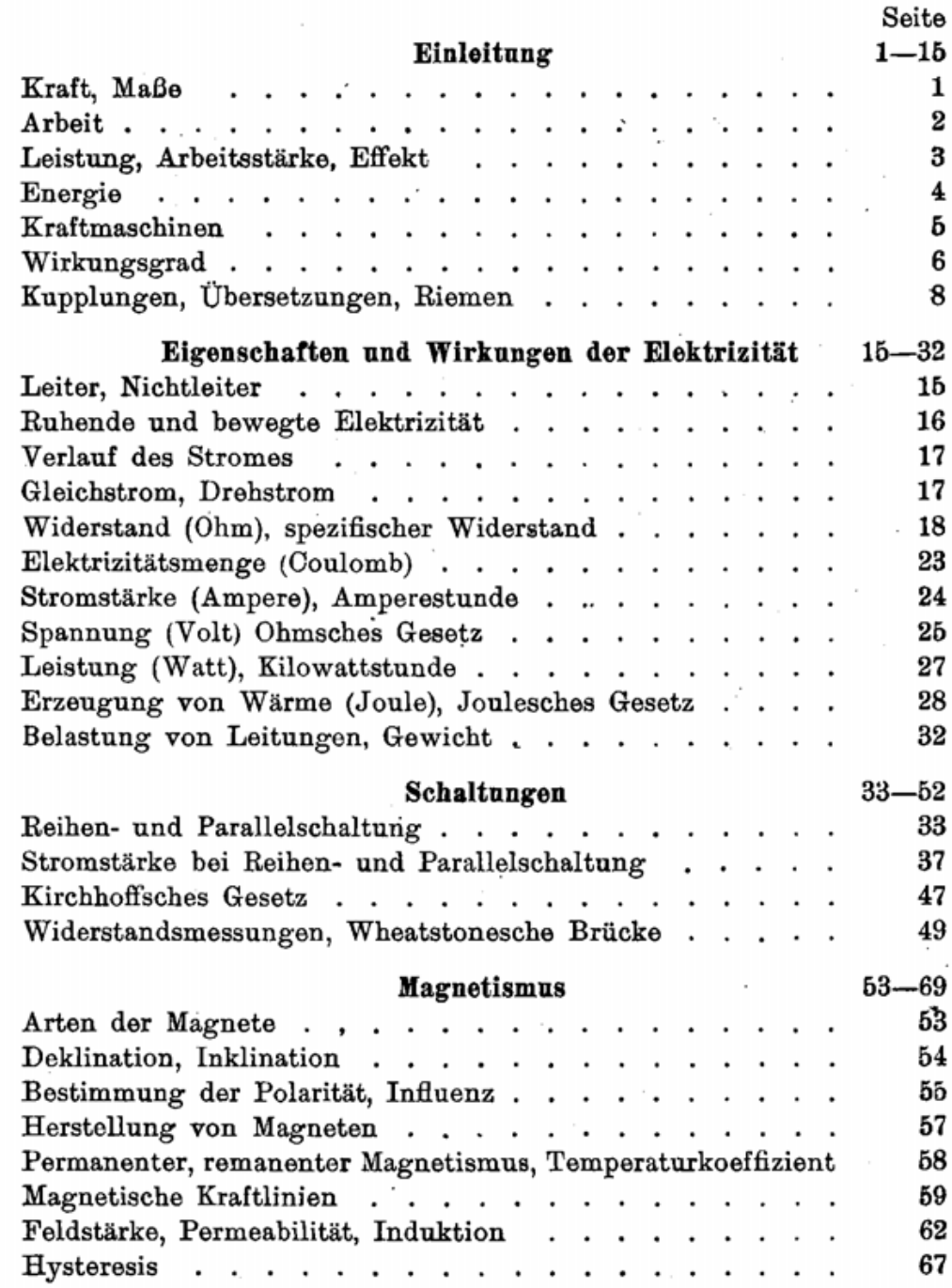


Kraftlinien

Amperesche Regel . . . . . . . . . . . . . . . . 70

Kraftlinien in Drähten und Spulen . . . . . . . . . . 70

Amperewindungen . . . . . . . . . . . . . . . . 73

Magnetomotorische Kraft, magnetische Stromstärke . . . . 76

Elektromagnete . . . . . . . . . . . . . . . . .

Induktion . . . . . . . . . . . . . . . . . . . 80

Selbstinduktion . . . . . . . . . . . . . . . . . 101

Wirbelströme . . . . . . . . . . . . . . . . . 103

Induktionsapparate . . . . . . . . . . . . . - . . 104

Kohdensatoren . . . . . . . . . . . . . . . . . 110

Atmosphärische Elektrizitat, Blitz, Blitzableiter 115-119

Dauer der Entladungen, Stromstärke . . . . . . . . . 115

Ausführung von Blitzschutzanlagen . . . . . . . . . 116

Sachregister $120-124$ 